\title{
Impact of Tax Effects on Profit Optimisation. Review of International Approaches
}

\author{
Serhiy Lyeonov ${ }^{1}$, and Lucia Michalkova ${ }^{2, *}$ \\ ${ }^{1}$ Department of Economic Cybernetics, Sumy State University, 57, Petropavlivska str., Sumy, 40030, \\ Ukraine \\ ${ }^{2}$ Department of Economics, Faculty of Operation and Economics of Transport and Communications, \\ University of Zilina, Univerzitna 1, 01026 Zilina, Slovakia
}

\begin{abstract}
.
Research background: Deteriorating economic conditions and the risk of an impending crisis underline the need for significant profit optimization, especially in the area of taxation.

Purpose of the article: The aim of this paper is to analyse and evaluate the conditions for the creation of a tax shield in the V4 countries on a theoretical level and to confront these findings with the value of the total tax shield in the countries in question.

Methods: This study uses the method of two-way analysis of variance with interaction, while also testing the assumptions of the model by normality tests, homogeneity test and post hoc tests (Scheffé and Tukey methods).

Findings \& Value added: A review of the sources of the tax shield shows that the tax systems in all the countries examined offer similar conditions for the application of tax shields. In a sample of more than 90000 companies, it was found that the level of the total tax shield given as the effective tax rate is similar in all countries examined (except Hungary). The branch of affiliation plays a role only in the environment of Hungarian companies, on the contrary, Slovak companies show homogeneity of the reported effective tax rate. Country and industry affiliation does not have sufficient explanatory power to predict the total tax shield. Conversely, other indicators of financial performance (operating profit) may be suitable indicators of the effective tax rate.
\end{abstract}

Keywords: tax shield; profit optimalisation; deprecation; effective tax rate

JEL Classification: $G 31, G 32, H 43$

\section{Introduction}

The current economic conditions, rising debt, a global downturn in economic performance and the risk of a protracted crisis are a challenge for businesses, and profit optimization has gained in importance. In order to achieve the highest possible profit, business managers solve

\footnotetext{
${ }^{*}$ Corresponding author: lucia.michalkova@fpedas.uniza.sk
} 
several tasks, such as optimizing the capital structure, reducing costs, as well as optimizing tax liability. Tax optimization and tax planning represent a complex system of decisions of financial managers in order to adjust (reduce) tax liability. This optimization can be achieved legally or illegally; such as tax avoidance or tax evasion.

Within this tax planning, the most important role is played by the tax shield, i.e. reducing tax liability by managing business activities so as to maximize tax deductions [1]. Depending on which expenses are the basis for tax planning, we distinguish between interest and noninterest tax shields. While interest and the debt tax shield play a role in optimizing the capital structure, the non-debt tax shield consists of a wide range of deductible items such as depreciation, research and development costs or loss carry forward.

In addition to profit after tax and tax liability, this phenomenon also affects the cash flow and value of the company. There is a split in the literature on the great impact of the tax advantage on the value of the company. Miller [2] states that the tax shield has zero value because, in a corporate and personnel tax system, the two effects cancel each other out. Other authors [3-6] quantify this advantage from $2.73 \%$ to $10 \%$. Most of these studies are aimed at US companies, but even when examining samples from other countries, the proportion did not differ significantly despite differences in tax systems.

The complexity of tax systems creates many opportunities for the creation of tax shields on a national and international scale. Each national tax system provides different conditions for optimizing corporate taxes and creating a tax shield. The aim of this paper is to analyse and evaluate the conditions for creating a tax shield in the context of the V4 countries and other European countries, focusing on four sources of the tax shield: interest, depreciation, R\&D costs and loss carry forward. These findings are confronted with the value of the effective tax rate as a proxy for the total tax shield. The effective tax rate is examined on a sample of 90,000 Visegrad Four enterprises through a two-way analysis of variance and relevant statistical tests.

The paper is structured as follows: in the first part, various approaches to quantification of the tax shield are reviewed, focusing on the specifics of national tax systems. This section also examines the four main sources of the tax shield in terms of its availability to businesses. The Methods section describes the pattern, variables, and two-way Anova procedure. In the last section Results and Discussion, we confront the theoretical findings and tax competitiveness ranking with the results of the model in order to answer the question of how significantly the conditions of national tax policy affect the value of the overall tax shield.

\section{Literature review}

\subsection{Approaches to tax shield valuation}

Ever since the first ground-breaking study by [7] and the subsequent work of [8], the tax shield has been defined as a tax saving arising from the tax deductibility of interest paid. The interest tax shield is quantified as the product of the corporate tax rate, the cost of debt and the value of the debt. Modigliani and Miller [7] modified this formula to assume perfect capital markets; then the tax is dependent only on the value of the debt and the tax rate and the cost of the debt is irrelevant. Liu [9] calls this approach "tax shield capacity".

The basic definition of a tax shield allows only interest as a source of tax advantage. Velez-Pareja confronts the definition of [7] in several papers [10,11]. He notes that the tax shield is dependent on operating profit (EBIT). The company achieves at least a partial tax shield if EBIT is positive. The partial tax shield represents the difference between the tax paid by an unlevered and a levered company. Velez-Pareja [11] realized his original analysis about the existence of a tax loss. A negative pre-tax profit means that the tax shield is not 
applied. Notwithstanding, if the tax system allows a loss carried forward, then the tax shield is not applied in one year, but is divided into two periods. This author distinguishes three risks associated with a tax advantage: the risk of debt default, the risk of market costs of debt and the operational risk associated with operating profit.

In addition to the mentioned models, tax profit optimization also takes into account shareholder taxation. Miller's [2] most commonly used model is based on the Anglo-Saxon (American) tax system, which allows double taxation of profits on the part of both the company and shareholders. If the corporate and personnel taxes are equal, then the effect of the tax advantage is cancelled and it does not matter the capital structure. The second effect that Miller deals with is the equality of the tax rate on dividends and interest (withholding tax). If these two effects are identical, then the effect of personnel taxation is zero and the tax shield is quantified according to [7]. Velez-Pareja [12] notes that the basic shortcoming is the equal taxation of shareholders and debt holders. This presumption only applies if the shareholders and the debt holders are the same person. In real companies, however, these people are different and the net value of the tax shield is not zero. A comparison of Miller's model and its modification according to Velez-Pareja [12] revealed that Miller's model does not reflect the value of the dividend when quantifying the net value of the tax benefit and systematically overestimates the value of the tax shield even if the shareholder and debt holder are the same.

The existence of personnel taxation and its implementation into the tax shield model encounters a barrier to the diversity of tax systems. Castillo, Niño and Zurita [13] responded to this by creating a general model of the value of the tax shield that is applicable in any tax system, regardless of the relationship between corporate and dividend tax. They created seven variations of the general model (for the classical system, modified classical system, dividend partial inclusive system, no shareholder taxation system, partially integrated or partially imputation system, fully integrated or fully imputation system and other systems). These variations fully cover the tax systems of OECD countries. Cnossen [14] examining EU systems notes that Member States other than Sweden and the UK do not levy a withholding tax on dividends. The diversity of tax systems in the EU determines the application of these modifications in practice.

The dividend distribution system in force in Estonia, Latvia (since 2018) and Georgia (since 2017) allows only part of the profit in the form of dividends to be taxed; retained earnings are not taxed. Taxation of only distributed profits has been shown to increase investment activity in order to minimize the tax burden [15]. Estonia, along with Latvia, has the first two places in the Corporate Tax Rank (International Tax Competitiveness Index) 2019 [16].

Tax shield models largely apply the terms of US tax systems; to a lesser extent, the conditions of other tax systems are included, mainly in the area of personnel taxes. In terms of sources of tax benefit, the main examined deductible cost is interest. Other sources of tax advantage are less explored than e.g. depreciation, research and development costs and tax loss. These other factors of the tax advantage vary depending on the tax system, despite some harmonization of the tax systems of the EU Member States. In particular, the conditions of the V4 countries may differ from other Member States of Western Europe. For this reason, it is necessary to explore the possibilities of tax optimization in these countries at the theoretical level and at the level of the effective tax rate as a proxy for the total tax shield.

\subsection{Sources of the tax shield in the V4 countries}

As mentioned in the previous subchapter, the most significant sources of tax benefit are the four tax deductible items: interest paid, depreciation, R\&D costs and tax loss deduction. From the corporate point of view, in addition to interest and decisions on the capital structure, 
depreciation is important for decisions on the method of acquisition of non-current assets (buy vs. leasing). Loss carry forward plays a similar role in the application of income smoothing or earnings management.

Interest expense and the capital structure of companies depend primarily on the development of interest rates in the economy. Despite the fact that only Slovakia belongs to the Euro area, interest rates in all V4 countries depend directly or indirectly on the development of ECB interest rates. Since 2015, the ECB has pursued a policy of quantitative easing (a policy of cheap money) aimed at supporting investment activity and economic growth. This policy is reflected in the extreme decline in interest rates to zero or negative values, as shown in Fig. 1

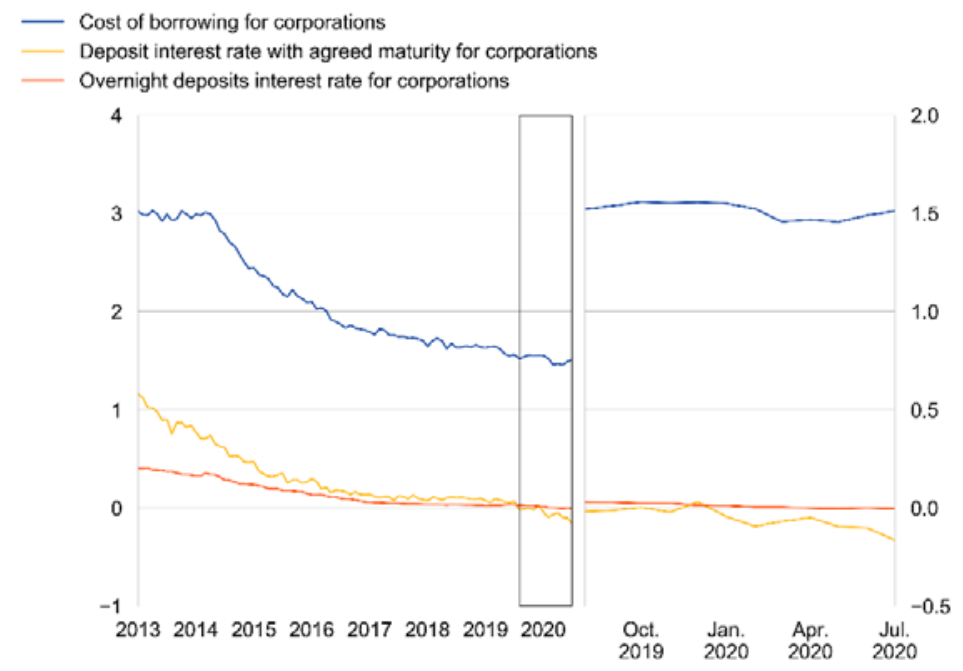

Fig. 1 Bank interest rates in Euro area to July 2020 [17].

The cost of borrowing as well as deposit interest rates and overnight deposit interest rates have been declining since 2015; in the first and second quarters of 2020, the cost of borrowing did not change significantly compared to the previous period. Based on the loan amount, these costs ranged from $1.17 \%$ to $1.96 \%$ [17]. Relatively low interest rates support the growth of corporate investment, however, they can have a negative impact on the value of the interest tax shield. The second negative of low interest rates is the extreme increase in corporate indebtedness and the increase in the risk of financial distress.

The tax deductibility of interest is conditioned by two factors: the link between the interest paid and the object of the business and the relationship between the debtor and the creditor. If these persons are related parties, then the tax shield is not recognized in full and thin capitalization is applied. The purpose of this is, firstly, to reduce the outflow of tax revenues of the state, and secondly to reduce the credit risk of companies (their indebtedness). The EU has introduced Council Directive 2016/1164 [18], known as the ATAD (The Anti-Tax Avoidance Directive), as part of the harmonization of thin capitalization and transfer pricing rules in the common market. This directive was implemented in all states of the European Union until 31.12.2018. European countries have implemented these rules in various ways, most often as the $25 \%$ EBITDA rule, i.e. the value of interest exceeding $25 \%$ of EBITDA is not tax deductible. Slovakia belongs to such countries; other countries such as Hungary, Poland, the Netherlands, Spain or Romania have introduced two variations of this rule $-30 \%$ of EBITDA or the maximum tax deductible interest expense. The Czech Republic, on the other hand, combines the $30 \%$ EBITDA model, the maximum interest value ( 80 mil. CZK), 
with the debt to equity ratio rule (4:1). A specific case is Austria, where the thin capitalization rule is not legally established; there is only a recommendation to apply the debt to equity ratio model 3: 1 or 4: 1 depending on the industry [19].

Depreciation is the second major source of tax benefits. The Slovak and Czech Republic share similar rules for depreciation and the existence of 6 depreciation groups of assets. In Slovakia, accelerated depreciation is permitted in only two depreciation groups and the longest depreciation period is 40 years. On the contrary, in the Czech Republic it is up to 50 years and accelerated depreciation is allowed in all depreciation groups. Polish companies can use accelerated depreciation only for certain assets; moreover, the Polish tax system favours companies by one-time depreciation for assets with a purchase price lower than PLN 10,000, or start-up companies can depreciate assets on a one-off basis up to PLN 50,000. Hungarian companies use a similar system, including straight-line depreciation, a depreciation period of 2 to 50 years and a one-off depreciation. Austria applies a relatively loose tax depreciation system, where depreciation rates are given only for certain types of assets [19].

R\&D costs are another important component of the overall tax shield by which the government wants to support the company's innovative policy. In the V4 countries, there is a growing massive support for these activities by tax benefits. In Slovakia, since 2015, the super-deduction has been growing from $25 \%$ of R\&D costs to the current $200 \%$ for the 2019 tax period. A total of 353 super-deductions in the amount of CZK 45.8 million were applied for the period 2015-2017. EUR, most entities were recorded in 2017 (158). The most represented industries were companies from NACE, industry C - Manufacturing [20].

The Czech Republic introduced a super-deduction of R\&D costs in 2005. The maximum value is $100 \%$ of $R \& D$ costs and an additional $10 \%$ quantified as the difference between the costs of the current year and the costs of the previous year. The overall development of R\&D costs in the Czech Republic is shown in Fig. 2.

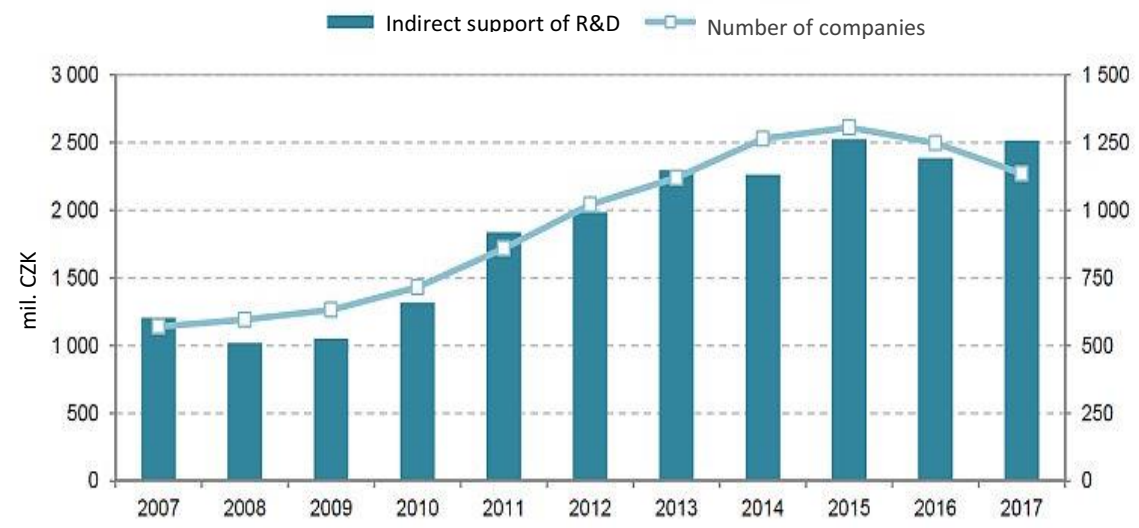

Fig. 2 R\&D cost in the Czech Republic since 2007 [21]

Compared to Slovakia, a disproportionately more companies used the tax advantage (1,135 companies in 2017). In terms of ownership, however, they were mainly foreign companies operating in the automotive industry. The number of enterprises in the last monitored period decreased compared to the peak in 2015 [21].

In Poland, since 2018 , the principle of $100 \%$ of R\&D cost or $150 \%$ (research centres) has been applied. Since 2019, it has adopted a patent box that allows for a $5 \%$ reduction in corporate tax on qualified intellectual property income [22]. Among the V4 countries, Hungary has the most favourable R\&D cost policy; $300 \%$ of R\&D up to 50 mil. HUF if the tax entity cooperates with a university or other research institution. Western European countries differently support the innovative activities of companies through R\&D. Denmark 
or the United Kingdom offer a super-deduction equivalent to $100 \%(130 \%)$ of the R\&D cost. Dutch and Austrian companies can take advantage of a tax advantage of $14 \%$ to $40 \%$ of the $R \& D$ cost, depending on the conditions set. As in the case of depreciation, Estonia and Latvia do not apply the R\&D cost advantage scheme, but in the dividend distribution system, the retained earnings used for $R \& D$ are not taxed [19].

The tax advantage of the loss is the last significant source of the tax advantage. The existence of a tax loss has a negative effect on the application of other types of tax shields in the year in which the tax loss arose. However, the taxpayer may carry all or part of the tax loss to subsequent tax periods. Slovak companies can carry a tax loss evenly over 4 consecutive periods; from 2020 up to $50 \%$ of the tax base for a period of 5 years from the occurrence of the tax loss. Micro-taxpayers, who must meet pre-determined conditions, are not limited by the condition of $50 \%$ of the tax base, they can write off the tax loss even once. Similar conditions apply in the Czech Republic and Poland; one-time deduction can be applied by all taxpayers regardless of the type of taxpayer (there is no group of microtaxpayers). Hungarian companies can offset losses before 2015 indefinitely until 2025, after this year for a maximum of 5 years according to the FIFO principle up to a maximum of $50 \%$ of pre-tax profit. Other EU countries can be divided into four groups: tax carried forward time limit (Finland - 10 years, the Netherlands - 9 years, Greece - 5 years, Luxembourg - 17 years); limit of percentage of year tax base (Denmark - 60\% of the tax base, Lithuania - $70 \%$ of the tax base, Slovenia - 50\% of the tax base); a combination of the previous ones (Portugal) and a dividend distribution system (Estonia, Latvia), which do not deduct the tax loss from the tax base [19].

\section{Methods}

The aim of this paper is to analyse and evaluate the conditions for the creation of a tax shield in the V4 countries on a theoretical level and to confront these findings with the value of the total tax shield in the countries in question. The previous chapter showed that the conditions for obtaining tax benefits are similar in these countries, which suggests that the value of the total tax shield may not differ.

This study analyses two qualitative factors, industry and country affiliation. The breakdown by country is given by the different conditions of tax systems and the possibility of achieving a tax shield. The second factor is industry; its classification is conditioned by the different financial performance of companies in the sectors. Also, according to data on the use of the R\&D cost deduction in Slovakia and the Czech Republic, this tax advantage is the most used by manufacturing companies (automotive industry). Industry membership was assigned according to the NACE rev. 2 . The total tax shield is estimated by an effective tax rate that reflects all tax benefits used by businesses.

A two-way ANOVA was chosen as a suitable method to test the impact of these factors on the total tax shield. In contrast to the one-way version, the method also analyses an interaction term indicating that the combination of both factors is significant for estimating the total tax shield. This method is subject to several assumptions (normality of subsets, homogeneity of variances, independence of cases and no outliers). These assumptions are tested by appropriate tests (Kolmogorov-Smirnov test, Levene's test) and outliers were removed by wisorizing at $1 \%$ and $99 \%$ percentile. If the assumptions are not met, then the two-way Anova is tested on a robust basis (with robust standard errors).

Eq. 1 shows a regression form of ANOVA.

$$
\operatorname{TAX}_{i}=\mu+\text { Country }_{j}+\text { Industry }_{k}+\text { Country } \cdot \text { Industry } y_{j \cdot k}+\varepsilon_{i j k}
$$

Where: $T A X_{i}$ - effective tax rate, $i=1,2, \ldots, 90324$ - number of case in net sample, Country $_{j}$ - qualitative variable $\{$ The Czech Republic, Hungary, Poland Slovakia\}, 
Industry ${ }_{k}$ - qualitative variable, industry classification according to NACE rev. 2, Country $\cdot$ Industry $_{j \cdot k}$ - interaction term

The sample for this study was obtained from the database Amadeus; two selection criteria were specified - total assets of at least EUR 1 million and the registered office of the company in one of the countries examined. The gross sample contained 91,154 companies and their financial indicators of 2018. SPSS program was used for the examination of samples and achieve the objective of the paper.

\section{Results and discussion}

The first step in analysing the impact of the tax system and sectoral structure on the overall tax shield is to analyse a sample of companies. The gross sample was primarily adjusted for enterprises with missing values of key variables. In the second step, outliers were detected via the $1 \%$ and $99 \%$ percentiles. These outliers were wisorized, making the sample larger than using other outlier removal methods. The net sample contained 90,324 businesses. The structure of enterprises by industry is shown in Fig. 3.

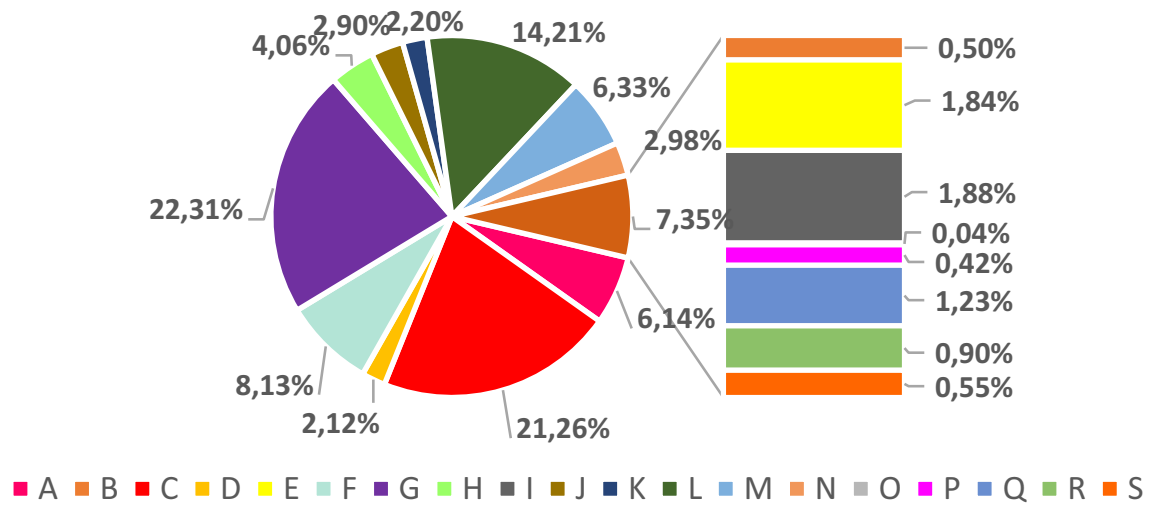

Fig. 3 Industry structure of sample.

Wholesale and retail companies have the largest share in the sample, while manufacturing companies have the second largest share in the sample. The real estate sector accounts for more than ten percent. Other sectors have a relatively lower share of the sample. Fig. 3 shows the non-uniformity of the sub-samples, which indicates that one of the ANOVA assumptions is not met. Subsequently, we examined the value of the total tax shield by descriptive statistics.

Table 1. Descriptive statistics of total tax shield (effective tax rate)

\begin{tabular}{|c|c|c|c|c|c|}
\hline Factor & \multicolumn{4}{|c|}{ Effective tax rate (total tax shield proxy) } \\
\hline Country & Mean & Median & $\begin{array}{c}\text { Std. } \\
\text { Deviation }\end{array}$ & $\begin{array}{c}\text { \% of Total } \\
\text { N }\end{array}$ & N \\
\hline the Czech Republic & 0,1275 & 0,1751 & 0,2079 & $23,55 \%$ & 21270 \\
\hline Hungary & 0,0715 & 0,0514 & 0,1412 & $21,96 \%$ & 19835 \\
\hline Poland & 0,1161 & 0,1036 & 0,2384 & $39,77 \%$ & 35926 \\
\hline Slovakia & 0,1579 & 0,2031 & 0,2467 & $14,72 \%$ & 13293 \\
\hline
\end{tabular}

The mean values of the effective tax rate indicate that Slovak companies are subject to the highest level of taxation, while Hungarian companies are the least taxed. The ranking of 
countries according to the average values of effective taxation corresponds to the values of statutory tax rates. On average, the surveyed companies achieve an overall tax advantage because their effective tax rate is lower than statutory. However, in terms of median values, Polish companies achieve the most significant tax advantage; on the other hand, Slovak companies to a small extent apply the tax benefits given by the state (the effective tax rate is close to the statutory one). However, the mean values of the total tax shield of Slovak and Polish companies have the largest deviation indicating a high number of companies that do not use / use tax shields to a small extent.

The analysis of variance is based on a set of assumptions that we tested. First, we tested the normality of the subsamples by the Kolmogorov-Smirn test at the level of 0.05. A significant difference between the mean and the median indicates that this criterion was not met, which was confirmed by the test results. The second assumption of homogeneity of subsample scatterings was also rejected. The reason for rejecting both assumptions may be due to inequality in the size of the subsamples. For these reasons, a two-way ANOVA with robust standard variances was used, this eliminates the occurrence of type I error. A summary ANOVA table is shown in Table 2.

Table 2. Summary table of two-way ANOVA

\begin{tabular}{|c|c|c|c|c|c|c|}
\hline Source & $\begin{array}{c}\text { Type III } \\
\text { Sum of } \\
\text { Squares }\end{array}$ & df & Mean Square & F & Sig. & $\begin{array}{c}\text { Partial } \\
\text { Eta } \\
\text { Squared }\end{array}$ \\
\hline Corrected Model & $115,130^{\mathrm{a}}$ & 75 & 1,535 & 33,660 & 0,000 & 0,027 \\
\hline Intercept & 81,776 & 1 & 81,776 & 1793,130 & 0,000 & 0,019 \\
\hline Country & 4,316 & 3 & 1,439 & 31,545 & 0,000 & 0,001 \\
\hline Industry & 31,251 & 18 & 1,736 & 38,070 & 0,000 & 0,008 \\
\hline Country * Industry & 16,829 & 54 & 0,312 & 6,834 & 0,000 & 0,004 \\
\hline Error & 4115,794 & 90248 & 0,046 & & & \\
\hline Total & 5428,389 & 90324 & & & & \\
\hline Corrected Total & 4230,924 & 90323 & & & & \\
\hline
\end{tabular}

R Squared $=, 027$ (Adjusted R Squared $=, 026$ )

The results of the model show that both examined factors significantly explain the changes in the value of the tax shield. The interaction term reports that the effective tax rate varies not only in different countries but also in different industries. The strength of the interaction between the factors is shown in Fig. 4 .

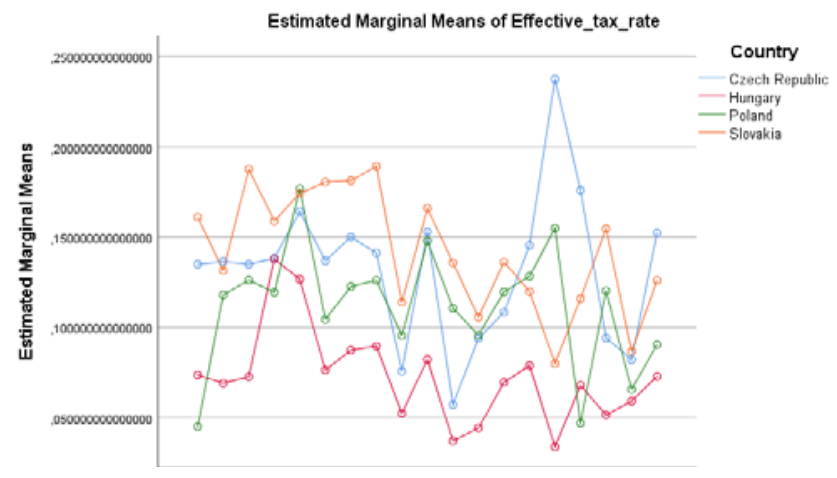

Fig. 4 Interaction between country and industry affiliation 
The strong interaction between the country and the industry indicates that, despite some harmonization of tax systems and the similarity of the conditions for achieving tax benefits, the effective tax rate varies in the countries and sectors monitored. We examined the difference in effective tax rates as simple main effects and performed a one-way ANOVA analysis for each country. This analysis has shown that the most significant difference between the total tax shield across sectors is shown by Hungarian companies. On the contrary, the tax advantage in Slovak companies does not change significantly on the basis of sectoral affiliation [23]. Polish companies have a significantly higher tax advantage in agriculture and, conversely, tax shields in the field of water management are applied to a very small extent. Overall, businesses in Central Europe (excluding Hungary) provide a similar rate of total tax shield regardless of country affiliation.

\section{Conclusion}

In conclusion, we can state that, as described in the theoretical level in Chapter 2.2, the tax systems of the V4 countries provide similar conditions for tax optimization of profits. However, the results of the ANOVA model describe that the explanatory power of the investigated qualitative variables is not sufficient. These results confirm the ranking of countries according to The International Tax Competitiveness Index 2019 - Corporate Tax rank, which ranked Hungary in fourth place, the Czech Republic in 9th place and Poland and Slovakia in 13. /14. place [16]. The financial performance of companies, or their operating profit $[24,25]$, have a higher impact on the value of the tax shield, as confirmed by VelezPareja [10]. For this reason, we propose to use a wider range of financial performance indicators in further research on tax profit optimization to create a comprehensive model of profit optimization.

This research was financially supported by the Ministry of Education, Science, Research and Sport of the Slovak Republic and Slovak Academy of Sciences VEGA 1/0121/20: Research of transfer pricing system as a tool to measure the performance of national and multinational companies in the context of earnings management in conditions of the Slovak Republic and V4 countries.

\section{References}

1. Raisova, M., Regaskova, M., Lazanyi, K. (2020). The financial transaction tax: an ANOVA assessment of selected EU countries. Equilibrium. Quarterly Journal of Economics and Economic Policy, 15(1), 29-48.

2. Miller, M.H. (1977). Debt and taxes. Journal of Finance, 32(2), 261-275.

3. Doidge, D., Dyck, A. (2015). Taxes and corporate policies: Evidence from a quasinatural experiment. Journal of Finance, 70(1), 45-89.

4. Kemsley, D., Nissim, D. (2002). Valuation of Debt Tax Shield. Journal of finance, 42(5), 2045-2074.

5. Clemente - Almendros, J., Sogorb-Mira, F. (2017). How much do the tax benefits of debt add to firm value? Evidence from spanish listed firms. Revista de Economía Aplicada, 25(74), 105-129.

6. Menichini, A. A. (2017). On the value and determinants of the interest tax shields. Review of Quantitative Finance and Accounting, 48(3), 725 - 748.

7. Modigliani F., Miller M.H. (1963). Corporate income taxes and the cost of capital. A correction. The American Economic Review, 53(3), 433-443. 
8. Brealey R.A, Myers, S.C, Allen, F. (2010). Principles of Corporate Finance. $10^{\text {th }}$ ed. New York: McGraw-Hill/Irwin.

9. Liu, Y. (2009). The slicing approach to valuing tax shields. Journal of Banking \& Finance, 33(6), 1069-1078.

10. Velez - Pareja, I. (2013). Return to Basics: Are You Properly Calculating Tax Shields? Análisis Financiero, 122, 6-17.

11. Velez - Pareja, I. (2016). Tax shield, financial expenses and losses carried forward. Cuadernos de Economica. 35(69), 663 - 689.

12. Velez - Pareja, I. (2017). Do Personal Taxes Destroy Tax Shields? A Critique to Miller's (1977) Proposal. Emerging Markets Finance and Trade, 53(10), 2199 - 2214.

13. Castillo, A., Niño, J., Zurita, S. (2017). Debt Tax Shields Around the OECD World. Emerging Markets Finance and Trade, 53(1), 26 - 43.

14. Cnossen, S. (2017). Corporation taxes in the European Union; Slowly moving toward comprehensive business income taxation? International Tax and Public Finance, 25(3), 808-840.

15. Kantsukov, M., Sander, P. (2018). A lesson in valuation from Estonia: the difference between the fundamental value of equity under distributed and traditional profit taxation systems. Verslas teorija ir praktika, 9(1), 146-156.

16. Tax Foundation (2019). The International Tax Competitiveness Index 2019. Washington: Tax Foundation.

17. European Central Bank (2020, September 2). Euro area bank interest rate statistics: July 2020. ECB. Retrieved from: https://www.ecb.europa.eu/press/ $\mathrm{pr} / \mathrm{stats} / \mathrm{mfi} / \mathrm{html} / \mathrm{ecb} . \mathrm{mir} 2007 \sim 61960 \mathrm{f} 8 \mathrm{a} 6 \mathrm{e} . \mathrm{en} . \mathrm{html}$

18. Council Directive (EU) 2016/1164.

19. PWC (2020). Worldwide Tax summaries. Retrieved from: https://taxsummaries.pwc.com

20. Financna sprava SR (2018). Zoznam danovych subjektov, ktori si uplatnili odpocet vydavkov na vyskum a vyvoj. Retrieved from: https://www.financnasprava.sk/sk/elektronicke-sluzby/verejnesluzby/zoznamy/zoznam-danovych-subjektov-kto

21. Veda a Vyskum (2019, April 12). Firem vyuzivajicich danove odpocty na vyzkum a vyvoj bylo opet mene. Retrieved from: https://vedavyzkum.cz/politika-vyzkumu-avyvoje/politika-vyzkumu-a-vyvoje/firem-vyuzivajicich-danove-odpocty-na-vyzkum-avyvoj-bylo-opet-mene.

22. Polish Investment \& Trade Agency (2019). Corporate Income tax. Retrieved from: https://www.paih.gov.pl/polish_law/taxation/cit\#81

23. Novak Sedlackova, A., Svecova, D., Tomova, A. (2019). Slovak Airports as Profit/Loss Making Entities: Consequences for Transport Policies. Journal of Tourism and Services, 10(19), 153-163.

24. Siekelova, A., Kovacova, M., Adamko, P., Stehel, V. (2019). Profit Management as an Instrument for SMEs Developing: The Case for Slovakia. Marketing and Management of Innovations, 3, 285-296.

25. Dvorsky, J., Petrakova, Z., Polach, J. (2019). Assessing the Market, Financial, and Economic Risk Sources by Czech and Slovak SMEs. International Journal of Entrepreneurial Knowledge, 7(2), 30-40. 